GLOBAL JOURNAL OF SOCIAL SCIENCES VOL 13, 2014: 41-49

COPYRIGHT@ BACHUDO SCIENCE CO. LTD PRINTED IN NIGERIA. ISSN 1596-6216

www.globaljournalseries.com; Info@globaljournalseries.com

\title{
THE ASSESSMENT OF THE EFFECT OF CORPORATE SOCIAL RESPONSIBILITY ON STAFF'S EFFECTIVENESS IN AIRTEL NIGERIA
}

\section{IDOWU O. OLOGEH., TEMITOPE O. OLORUNFEMI AND ILEVBARE OLUWATOSIN}

(Received 30 May 2014; Revision Accepted 8 July 2014)

\begin{abstract}
Corporate Social Responsibility (CSR) integrates major areas of an organisation, including community, environment, ethics, workforce, human rights, responsibility in the market, vision and values and workplace. Much work has been done on the organization giving back to the environment and community; however other areas are rarely covered. The workforce is one of the major stakeholders of an organisation; it is an internal part of it and can either promote or tarnish the CSR image of the organization. Staff are part of an organizations' CSR success and this paper assesses the impact of Airtel Nigeria's CSR on staff' effectiveness and satisfaction at work. Structured questionnaires are administered to forty randomly selected staffs and two managers are interviewed from the two founding branches of the organization. The study shows that majority $(57.5 \%)$ of the respondents do not understand the meaning of CSR; they see it as the organization being charitable and thus find it difficult to accept it affects their effectiveness and performance at work. However, Airtel Nigeria did not relent in their CSR duties to staff and community. Thus the organization should provide effective CSR training and communication to enlighten their workforce on their CSR activities for staff.
\end{abstract}

KEYWORDS: Corporate Social Responsibility, Airtel Nigeria, Employee effectiveness, Internal Communication, Staff's wellbeing

\section{INTRODUCTION}

Corporate Social Responsibility (CSR) is a concept whereby organizations consider the interests of society by taking responsibility for the impact of their activities on customers, suppliers, staff, shareholders, communities and the environment in all aspects of their operations. It implies a sense of obligation and accountability of individuals and institutions to the society beyond their primary functions. CSR integrates major areas of an organisation, including community, environment, ethics, workforce, human rights, responsibility in the market, vision and values and workplace (Robinson \& Bennett, 1995). CSR is a guiding principle for every decision made in every area of a business (Kinkhabwala, 2004) and has been a useful tool in risk management, environmental sustainability, building the organization's image, public administration etc. The major social concerns include the welfare of the key stakeholders in the business, especially staff (Health and Safety Executive, 2005). This obligation entails organizations voluntarily taking further steps to improve the quality of life for staff and their families as well as for the local community and society at large.

\section{The Background of Airtel Nigeria}

Airtel Nigeria, an Indian owned organization has over the years changed in name and appearance. As ECONET wireless Nigeria,

Idowu O. Ologeh, Research Consultancy and Collaboration Department, National Centre for Technology Management, Obafemi Awolowo University, Ile-Ife, Nigeria.

Temitope O. Olorunfemi, Research Consultancy and Collaboration Department, National Centre for Technology Management, Obafemi Awolowo University, Ile-Ife, Nigeria.

Ilevbare Oluwatosin, Research Consultancy and Collaboration Department, National Centre for Technology Management, Obafemi Awolowo University, Ile-Ife, Nigeria. 
Airtel Nigeria was one of the three winners of the highly competitive Nigeria's GSM license bid in 2001. It was transformed to Vodacom owned by Vee Networks Limited Nigeria on the 15th of March 2004. In 2006, following Celtel International's acquisition of majority stake in the organization, it was re-named Celtel. Celtel Nigeria was re-branded Zain Nigeria on August 1, 2008, following the global acquisition of Celtel International by MTC Group, which transformed to Zain Group, a leading emerging market player in telecommunications. On November 19, 2010, Zain was again transformed into the current Airtel following the acquisition of Zain by Bharti Airtel of India for $\$ 10.7$ billion in June that year.

The change of name brings to fifth the number of times the organization would change identity since 2001 it started operations in Nigeria. Nigeria is the telecoms biggest market on the African continent with over 16 million subscriber base. It is gathered that its 16 country Africa subscriber base is over 40 million (GSMA, 2013).

The CSR department of Airtel Nigeria seeks to provide socially responsible products and services to Nigerians as well as sponsor projects that will enable sustainable growth in areas of leadership, education, health, environment and building meaningful relationships with their stakeholders. The organization's major CSR initiative is to select primary schools under its adopt-a-school programme. Airtel Nigeria will under the programme renovate and rebuild the selected schools, provide learning materials for the pupils, re-train teachers and continuously support the schools for an indefinite period (Bayagbon, 2012).

\section{Literature Review}

The history of CSR can be traced to the $17^{\text {th }}$ century when the Quakers operate business with the intention of adding value to the society at large; business was framed as part of the society and not separate from it (Amaeshi \& Adi, 2006). Some two decades ago, CSR attracted low interest from developing countries, but as more people are educated and thus enlightened, most Nigerians now know their rights and what to expect from organizations around them (Amaeshi, Bongo, Adi \& Olufemi, 2006).

Although, a lot of work has been done on CSR, not much work has been done on its impact on the workforce; the role of management and its effect on staff, especially in Africa. The focus has typically been on the organization's image, the environment, customers and shareholders. Staff however are very important part of an organisation, and of CSR. The staff are the main components that make up an organisation; this was confirmed by a study carried out by Story and Price in 2006 on CSR compliant organisations in the United Kingdom. Their study shows that organizations chose staff as being important to their CSR success, key performance indicators (KPI), benefits and rated their staff as key stakeholders.

Training on CSR is important for staff; in some countries, it is required by government regulations. It is another way of changing the behaviour of corporations; a corporation is made up of its staff. Training aims at helping staff make ethical decisions. Tulberg \& Tulberg (1996) said humans are created with the capability to cheat and manipulate, hence the need for learning normative values in human behaviour. Training directly reduces the likelihood of bribery, fines and damaged reputations for breaching laws and moral norms. It also increases employee loyalty and pride to the organization.

Both the quality and extent of the relationship between a business and its staff can be regarded as a precondition for Corporate Social Responsibility, (Tziner, 2013). Psychologically, a staff' attitude towards ethical business and CSR activities builds a road-map towards building a culture of better ethics and corporate integrity, (Kumari, 2013). CSR enhances employee attitudes, behaviors, and productivity in the workplace and thus contributes to companies' profitability, (Tziner, 2013). Furthermore, a positive relationship has also been found between CSR policies and organizational commitment among staff (Brammer, Millington, \& Rayton, 2007; Turker, 2009), leading to a rise in employee performance, low personnel turnover; both costly to the growth of an organization, (Aguilera, Rupp, Williams, \& Ganapathi, 2007; Soloman \& Hansen, 1985).

Johnston (2001) asserted that if a company does not assume a high level of responsibility toward its own staff, it is unlikely to do so toward its customers or the social and natural environment in which it operates. Aguinis and Glavas (2013) further reiterated that working 
for an organization that cares (socially responsible) fosters a robust and healthy relationship between staff' individual values and the organizations' values (organizational culture), which may lead to positive work attitudes such as job satisfaction. This study is a development on Story and Price's (2006) work, it carried out a survey into how CSR related activities develop, influence and help staff at work. The research also seeks to assess if CSR improves staff's effectiveness and satisfaction at work, rather than improving the organization's image alone.

The significance of the study is for organizations to see their staff as their asset and key stakeholder, thus enhancing their lives and for the workers to know the importance of CSR and how it affects their work and lives.

\section{Methodology}

Airtel Nigeria is chosen for this study mainly because of their frequent brand change as this may affect their staff's orientation. Airtel has eleven (11) outlets in Lagos, but two outlets: Sanusi Fafunwa, Victoria Island and Oba Akran Road, Ikeja were chosen for this study. The reason being these branches are the founding branches of Airtel (then Econet) and most patronized. The sample size is forty staff (out of a total of about one hundred and five staff) and two managers. The research instruments used are structured questionnaire and face to face interview. The managers of the branches were interviewed while questionnaire were administered to the staff.

\section{RESULT AND DISCUSSION}

\section{Socio-Economic Background of the Respondents}

In all forty staff were surveyed from two different Airtel Nigeria branches (Victoria Island and Ikeja) in Lagos. Almost all of the staff surveyed (97.5 percent) were between the ages of 26 and 34 years. This may be due to a current recruitment trend in the country, in which most private companies seek to employ young graduates for their entry level recruitment and young professionals for managerial levels. For example, the banking sector and most telecommunication industries do not employ applicants above 26 years of age (fresh graduates) and 35-40 years of age (experienced applicants), except the prospective applicant has exceptional qualities (Maiturare, 2003).

Also, 65 percent of the surveyed staff were female, while 35 percent were male. It is observed that a reasonable number of technical (science and engineering) staff were women. This is encouraging as this profession is in the past dominated by men (Bryner, 2007). Also, majority of the support staff e.g. secretaries, customer service representatives and marketers are also women.

The major departments in Airtel Nigeria were telecommunication, training and development, customer care and sales. As expected, Airtel Nigeria, being a telecom organization, have a majority of the sampled staff $(60 \%)$ in the telecom department. This is followed by the customer care department $(15 \%)$. This shows the management priority is in place, as the technical staff outnumbered the support staff and not vice versa as it is the practice in most organisations operating in Nigeria (Glennie \& Mays, 2009)

\section{Rate of Staff's Turn -over}

The study shows that Airtel Nigeria has been experiencing low staff's turnover. The organization has been in existence for 13 years and 27.5 percent of the respondents have been working with them from the very start. 60 percent have been working in Airtel Nigeria for four to eight years, while 12.5 percent have less than four years' experience. When interviewed, the managers indicated that the level of staff's turnover is between $0-20$ percent. One of the managers explained that the figure represents staff that travel abroad or took up appointments in other telecom companies in search of greener pastures rather than dissatisfaction at work. The two managers cannot ascertain if CSR contributed to the low level of staff's turnover.

\section{CSR Awareness Training (Ethical Training)}

The CSR department of Airtel Nigeria (AN) looks after the welfare and interests of their stake holders. The two surveyed managers indicated that there is CSR awareness programme for staff, at two stages: induction stage and advanced stage. The induction stage covers all aspects, while the advanced stage focuses on their responsibility to the community. No clarity is given pertaining to what time of the 
year the training is conducted or which categories of staff were trained.

In agreement with the managers, 42 percent of the forty employee respondents confirmed they had passed through the CSR awareness programme; however, 45 percent claimed they have not attended such programmes and 13 percent were not sure (Figure 4.1).

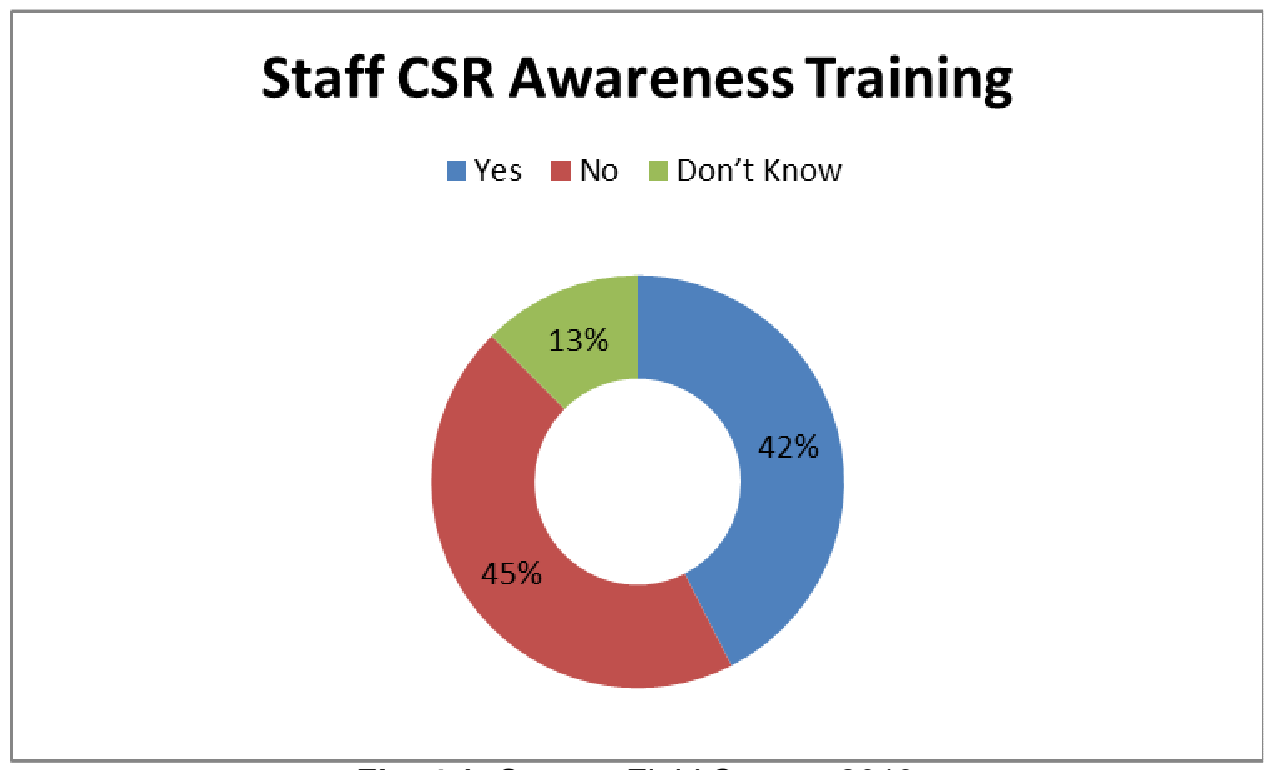

Fig. 4.1: Source: Field Survey, 2013

This shows that less than 50 percent of the respondents are cognizant of the CSR awareness programme. It has been proved that ethical training is one method that is gaining increasing popularity among corporate companies as a way of adding visibility to their CSR. Staff's awareness and behaviour plays a major role in CSR activities of an organization because it reduces negative organization's image. The management of the two Airtel Nigeria branches surveyed, needs to train and retrain all staff on CSR awareness.

\section{Cost of CSR/Ethical Training}

The two managers that participated in the interview survey gave an average of $\mathrm{N1}, 500$, 000.00 (approximately $\$ 9,375.00$ ) as the cost of annual CSR awareness training for each of the branches. This figure explains why almost half of the sampled population are not trained; the CSR training cost for the branches, especially the Victoria Island branch is not sufficient for proper annual CSR awareness training.

\section{Effectiveness of CSR Awareness Training}

The two managers rated the effectiveness of CSR training as "four" on the scale of 1-5, (with 5 as the highest and 1 the lowest). However, a significant percentage of respondents that has undergone training, (35.1 percent), cannot enumerate what effect CSR training has on them. This means they either did not benefit from the training or they do not know how to apply the training to their everyday work. Furthermore, 21.6 percent out of the remaining 64.9 percent rated the training as "three" using the same scale as the managers, while 15.2 percent each rated the training as "four" and "five". It can be deduced that in contrast to the managers' claims, only 30.4 percent respondents rated the training as four and above, this portrays the level and quality of training the staff are exposed to and the importance attached to the training (Figure 4.2). If the training is sound, and the staff are not told its importance, it will not have much effect on them. 


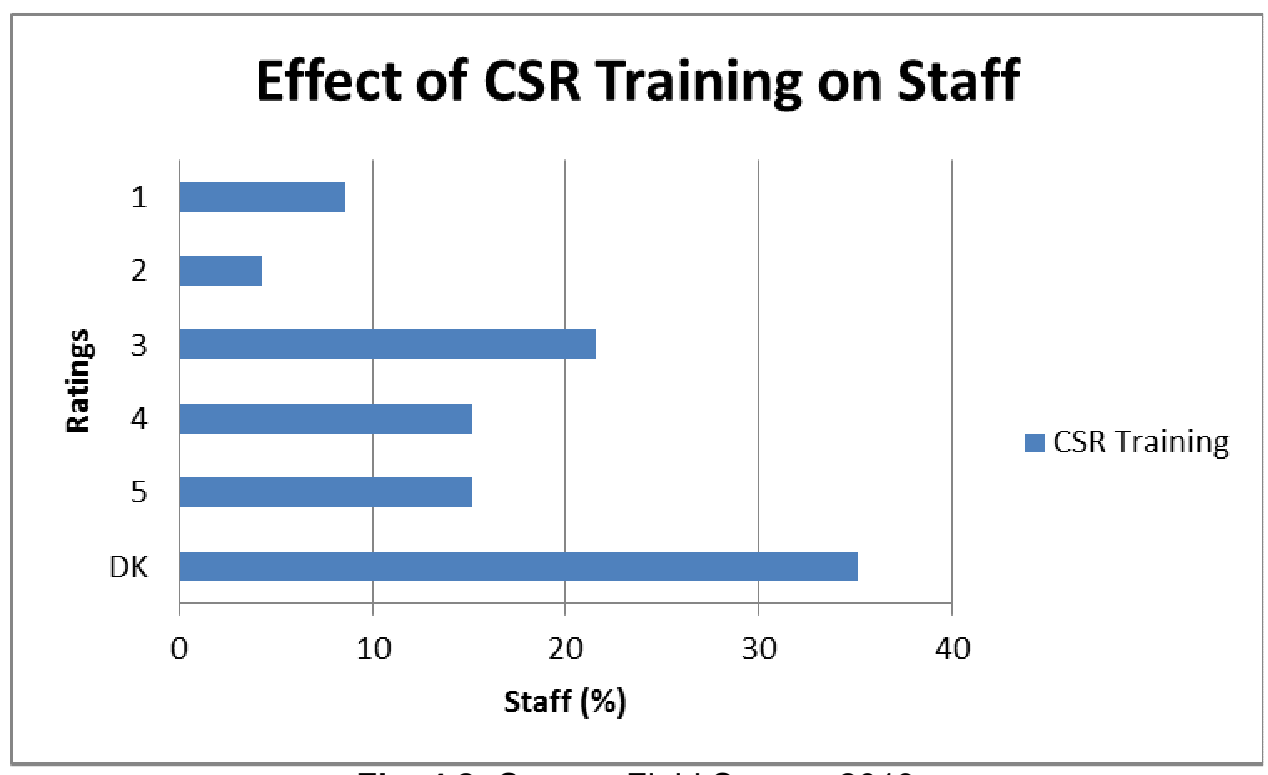

Fig. 4.2: Source: Field Survey, 2013

\section{Staff's knowledge of CSR}

The staff were asked whether or not they have heard about CSR before joining Airtel Nigeria, 75 percent of the respondents indicated that they have heard about it, 22.5 percent have not and others 'do not know'. When asked to describe the meaning of CSR, as anticipated, most staff's description was largely framed to reflect the duty of the organization to the environment in which it is situated. The definition of CSR from the responses can be summarized as "the corporate organization's obligation to be sensitive and responsible to the need of staff and community in which they operate". CSR was also defined as "the voluntary contributions of an organization to its immediate society and environment" or simply as "an organization giving back to society"

\section{Continuous CSR Awareness Scheme}

Through the interview survey, it was observed that the activities of the CSR department were mainly communicated to staff through the CSR newsletter. In response to more effective ways of communicating CSR activities, 42.4 percent of the respondents preferred e-mail, and 33.9 percent were "ok" with the bulletin. Some creative suggestions include the use of CSR related video/DVD and conducting CSR symposia. The use of ICT should be largely engaged in publicising CSR to staff and the public. Apart from the use of email, CSR blogs can be created where recent issues can be discussed and readers can respond instantly. Also, bulk SMS (Short Message Service) can be sent to all staff to introduce new CSR activities to the staff.

\section{Impact of CSR training on Staff}

Describing the impact of CSR training on the way they work, the response was averagely distributed with "promoting Organization's image" $(22.2 \%)$ and 'giving back to the society' $(21.0 \%)$ topping the list. Other items on the list include: compliance with government regulations, customers satisfaction, being a good ambassador and shunning "dirty hands" (bribery). In the same manner, in response to what they do differently as the result of CSR training, there is an even distribution with "consciousness of protecting organization's reputation" topping the list $(21 \%)$. The next on the list is "promoting corporate sustainability" (17\%), followed by "improved quality awareness" and "enhanced employee' social security" (16\%).

\section{Staff's Effectiveness Measuring Staff's Effectiveness}

In Airtel Nigeria, the key indicator in measuring staff's effectiveness at work is 
"customers' satisfaction". This was observed when the managers were asked to choose from a list, the factor that best determines staff's effectiveness. The factors were; less sick leave, customers' satisfaction, meeting targets, less accident reports, punctuality and working with enthusiasm. In a follow up interview, one of the managers explained that if the customers are happy, then they are successful. Another key factor mentioned was "meeting targets", if individual targets are met, the organization as a whole will achieve its own targets.

\section{Staff's Support Packages to Boost Effectiveness \\ CSR entails giving back to the} stakeholders, part of which is staff. Airtel Nigeria, has a variety of support packages as a way of giving back to the staff. The most highly rated scheme by the respondents is 'staff's bonuses' followed by 'pension scheme'. The managers also in their response rated 'pension scheme' first. The high rating for pension scheme can be explained; most Nigerian private companies do not have pension schemes, they pay their staff off during retirement. Airtel Nigeria pension scheme is a plus to their staff, so also Airtel Nigeria is one of the companies in Nigeria who pays well.

Most respondents do not believe CSR makes them effective nor give them job satisfaction. Only 38.5 percent of the respondents claimed otherwise "(Figure 4.3)". Also it can be said that what is not known cannot give satisfaction; some of the respondents were not trained and may not know the benefits of CSR.

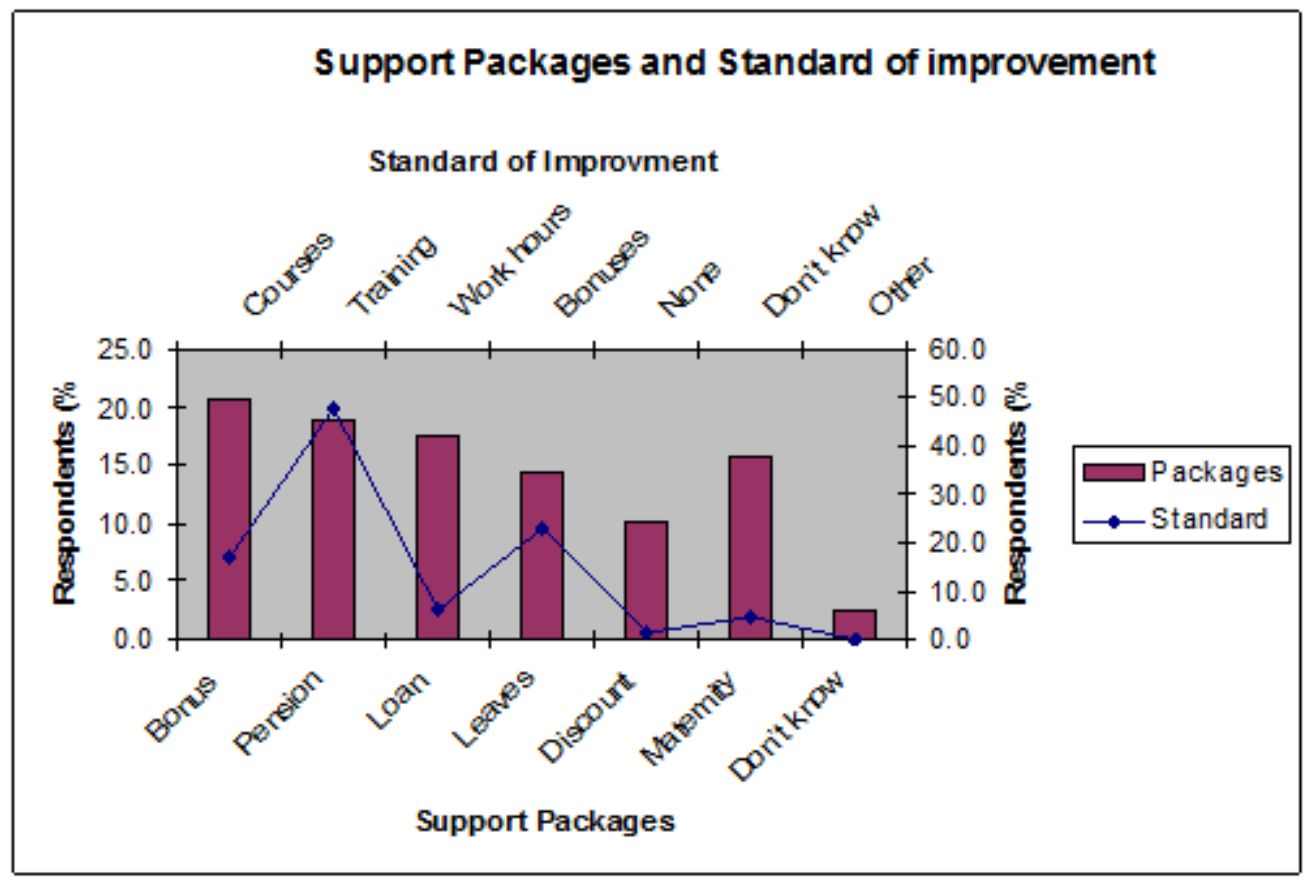

Fig. 4.3: Source: Field Survey, 2013

\section{Publicizing CSR Activities}

Airtel Nigeria continually communicates the CSR activities both within and outside the organization's walls and with the Nigerian press.
Their CSR publicity can be assessed on their website and seen on newspapers. Some of the CSR activities of AN includes: renovation of primary schools, scholarships for tertiary 
students, Flexible call packages, sponsoring reality shows among others.

\section{The level of CSR practised in Airtel Nigeria}

In relation to the grouping of Business in the Community (BITC) stated on their website www.bitc.org.uk, Airtel Nigeria CSR is on level two, having passed all requirements for level one and two to their best ability. As an organization operating in Nigeria, they have done more than average and indeed deserve a credit. Airtel Nigeria can decide to stay on this level and improve some parameters such as training and equal opportunity, or decide to work on their level 2 weaknesses and move on to level three. In order to improve and move on to level three, Airtel Nigeria has to concentrate on:

- Value of training and development
provided to staff
Workforce profile compared to the
community profile for the travel to work
area or equivalent
Impact evaluations carried out as a result
of downsizing, re-skilling etc.
Perception measures of the organization
(e.g. equal opportunities, work/life
balance)

\section{RECOMMENDATIONS}

Airtel Nigeria is an active player in CSR news in Nigeria. Recently, the organization was awarded for its CSR contributions; this was recorded in Tribunes newspaper of Thursday, 10 May 2012. However, based on the assessment of their CSR activities to staff, the organization can do more to improve their CSR image to their stakeholders, especially their staff. There can be improvement if the following measures are employed:

Training: Airtel Nigeria should ensure all staff are trained. This will go a long way to affect the way they think and thus influence the way they work. CSR cannot have impact on the way staff carry out their duties if they do not know what it is all about. To this effect, more resources should be invested in CSR training, at least N3, $000,000.00$ (approximately $\$ 18,750.00$ ) should be budgeted for annual CSR staff training. The investment will be worthwhile on the long run, as staff will be trained on how to promote the organization's image positively, comport themselves in an acceptable manner, shun bribery and enhance quality customers' service. Seasoned CSR facilitators should be invited for the training to give quality to the importance of the training rather than using CSR staff that they are familiar with.

CSR Communication: Airtel Nigeria is on the lead in communicating their CSR activities to all stakeholders through the use of the press; they should also strive in improving their internal CSR communication. This can be achieved by augmenting CSR bulletins with ICT empowered methods e.g. email, relevant websites, online social networks etc. These means are easier, faster and cost effective in updating the staff on CSR activities. Also, the content of the bulletin or email should be reviewed to reflect the meaning, importance and impact of CSR to the staff. From the study, many staff know about CSR activities but not many understand what it is about.

Staff's development: It is observed in the survey that CSR trainings are in-house. The organization should endeavour to sponsor some staff for professional courses on CSR to develop their competence, broaden their view on their role to their environment and increase the competitive edge of the organization.

Continual Improvement: Airtel Nigeria should device other means to practice continual improvement. Examples include reviewing the CSR policies and making necessary improvement.

\section{CONCLUSION}

From the study, it can be concluded that Airtel Nigeria has an effective CSR in place operating under the Safety Health and Environment department. Airtel Nigeria operates a standard CSR when bench marked with international standard. It incorporates the interest of all stakeholders, but too much emphasis was made on social activities (giving to the community). The CSR system in Airtel Nigeria reflects the national business systems of their home country-India, operating within the corporate governance framework and socioeconomic conditions influencing Nigerian indigenous firms. The company works to 
incorporate the conflicting culture of two communities while being loyal to both.

The CSR activities of Airtel Nigeria are efficient and evident to the community, the personnel also enjoyed some benefits of a CSR certified company but do not know it due to poor knowledge of what it's about. Thus CSR activities in Airtel Nigeria are well known to staff that do not recognise them. Airtel Nigeria is not effective in CSR training which explained the responses of their staff, they do not also make the meaning of this well publicized topic known to staffs. Airtel Nigeria do not conform to the norm of Nigerian socio-economic environment by providing good packages for staffs including pension packages which the Nigerian government is struggling to provide. On the other hand, they conform because they were somewhat bias towards practicing equality due to kingship norm of a typical Nigeria society. Finally, Airtel Nigeria is putting in their best by practicing an excellent CSR by Nigerian standard, but they still have some fall short when defined by western standards

\section{REFERENCES}

Aguilera, R. V., Rupp, D. E., Williams, C. A and Ganapathi, J., 2007. Putting the $S$ back in corporate social responsibility: A multilevel theory of social change in organizations. Academy of Management Review, 32, 836-845.

Aguinis, H and Glavas, A., 2013. Embedded versus Peripheral Corporate Social Responsibiltiy:

foundations. Industrial and Organizational Psychology: Perspectives on Science and Practice, 6, 1-40.

Amaeshi, K. M and Adi, A. B., 2006. Reconstructing the Corporate Social Responsibility Construct in Utlish. No. 37-2006 ICCSR Research Paper Series ISSN 1479-5124

Amaeshi, K. M., Bongo, C., Adi, C. O and Olufemi, O. A., 2006. Corporate Social Responsibility (CSR) in Nigeria: Western Mimicry or Indigenous Practices? No. 392006 ICCSR Research Paper Series ISSN 1479-5124
Bayagbon, E., 2012. Airtel at two: Leading Innovative Services in Nigeria's Telecom Industry.http://www.mobileworldmag.com /airtel-2-leading-innovative-services-innigerias-telecoms-industry/[25 October, 2013]

Brammer, S., Millington, A and Rayton, B., 2007. The contribution of corporate social responsibility to organizational commitment. The International Journal of Human Resource Management, 18, 1701-1719.

Bryner J., 2007. Why Men Dominate Math and Science Fields. Live Science Online http://www.livescience.com/1927-mendominate-math-science-fields.html [23August, 2013]

Glennie J and Mays, T., 2009. Policy in Distant Education: Staffing Issues. South African Institute of Distant Education (SAIDE) Website: www.saide.org.za / [4 November, 2013]

Green Power for Mobile., 2013. Powering Telecoms: West Africa Market Analysis Sizing the Potential for Green Telecoms in Nigeria and Ghana http://www.gsma.com/mobilefordevelopm ent/powering-telecoms-west-africamarket-analysis [6November, 2013]

Health and Safety Executive (HSE)., 2005. Promoting health and safety as a key goal of the Corporate Social Responsibility agenda. Research Report 339.

Kinkhabwala, B. A., 2009. Company Secretary and Corporate Social Responsibility [CSR].http://www.icsi.edu/cs/April2009/Ar ticles/Company percent20Secretary percent20and percent20Corporate percent20Social percent20Responsibility percent20 percent5BCSR percent5D percent20by percent20Bhavesh percent20A. percent20Kinkhabwala percent202.pdf. [3 September, 2013]

Kumari, N., 2013. Understanding the Employees' Psychology towards Ethical Business 
and Corporate Social Responsibility Activities. European Journal of Innovative Business Management, Volume 1: 9-16, 2013.

Maiturare, M. N., 2003. Entry and Competition in Concentrated Market: A Study of Nigerian Commercial Banks. Retrieved November 5, 2013, from University of Zaria, Zaria. http://www.freewebs.com/bizadmin/public ation1.htm [5 November, 2013]

Robinson, S. L and Bennett, R. J., 1995. "A typology of deviant work place behaviours: A multidimensional scaling study." Academy of Management Journal, 38, 555- 572.

Solomon, R. C and Hanson, K. R., 1985. It's good business. New York: Atheneum.

Story D and Price T., 2006. Corporate Social Responsibility and Risk Management? The Journal of Corporate Citizenship, Issue 22,

Tullberg, S and Tullberg, J., 1996. "On Human Altruism: The Discrepancy between Normative and Factual Conclusions". Oikos $\quad 75, \quad(2)$ : 327-329. doi:10.2307/3546259. ISSN 0030-1299. JSTOR 3546259.

Turker, D., 2009. How corporate social responsibility influences organizational commitment. Journal of Business Ethics, 89, 189-204.

Tziner, A., 2013. Corporative social responsibility (CSR) activities in the workplace: A comment on Aguinis and Glavas. Journal of Work and Organizational Psychology, 29, (2013), 91-93. 